https://helda.helsinki.fi

\title{
The influence of high tunnel on yield and berry quality in three floricane raspberry cultivars
}

\section{Palonen, Pauliina}

2017

Palonen , P , Pinomaa , A \& Tommila , T K 2017 , ' The influence of high tunnel on yield and berry quality in three floricane raspberry cultivars ', Scientia Horticulturae, vol. 214 , pp. 180-186 . https://doi.org/10.1016/j.scienta.2016.11.049

http://hdl.handle.net/10138/308521

https://doi.org/10.1016/j.scienta.2016.11.049

cc_by_nc_nd

acceptedVersion

Downloaded from Helda, University of Helsinki institutional repository.

This is an electronic reprint of the original article.

This reprint may differ from the original in pagination and typographic detail.

Please cite the original version. 
1 The influence of high tunnel on yield and berry quality in three floricane raspberry cultivars

3 Pauliina Palonen*, Anni Pinomaa, Tero Tommila

4 Department of Agricultural Sciences, PO Box 27, Fl-00014 University of Helsinki, Finland

5 * Corresponding author, Tel.: +358 2941 58333, E-mail address: pauliina.palonen@ helsinki.fi (P. Palonen)

7 Abstract

8 Growing raspberries in polyethylene tunnels is becoming more and more common. We wanted to examine

9 the effect of high tunnel growing conditions on yield and berry quality in three floricane raspberry cultivars,

10 'Glen Ample', 'Glen Dee', and 'M aurin Makea', under Northern high-latitude conditions. Compared to the

11 open field, fruit yield per cane was doubled in the tunnel. Fruit bioactive properties, including phenolic

12 compounds and antioxidant activity, were not affected by the tunnel growing conditions. Of the cultivars

13 investigated, 'Glen Dee' fruit had the lowest concentration of total phenolics. In the open field, the total

14 phenolics content in 'Glen Ample' berries was 48\% higher than 'Glen Dee'. Berries grown in the open field

15 had higher contents of soluble solids ( ${ }^{\circ}$ Brix) and higher titratable acidity than those grown in the tunnel.

16 Additionally, 'Glen Ample' and 'M aurin Makea' berries were sweeter than 'Glen Dee' berries. In conclusion,

17 raspberry production in polyethylene tunnels may provide major benefits through increased fruit yield.

18 While fruit bioactive properties were not affected, sensory taste may be different, however, as berry

19 sweetness and acidity were decreased in the high tunnel.

21 Keywords: acidity, antioxidant activity, phenolics, Rubus idaeus, soluble solids

1. Introduction 
24 Raspberry (Rubus idaeus) production in the world has nearly doubled over the past 20 years (FAOSTAT, 2016). Growing public awareness of the putative health benefits of berries and greater interest in healthy diets has increased the demand of the fruit. Raspberries are commonly sold in the fresh market, and long shelf life is an important quality parameter. Because of the superior fruit quality and shelf life when produced in a protected environment, more and more raspberries are grown in polyethylene tunnels. In some countries, in fact, this is a requirement set by the supermarkets. Polyethylene tunnels have also been reported to increase yields and extend the season (Hanson et al., 2011; Fernandez and Perkins-Veazie, 2013; Xu et al., 2014).

M any environmental parameters in the tunnel are different from the open field, including light intensity and quality, temperature, humidity, wind, as well as pest and disease pressures. In high tunnels, long cane plants are commonly used and grown in substrate. Little information, however, is available on the influence of these altered growing conditions on internal berry quality including taste, and nutritional and healthrelated compounds, especially in Northern high-latitude conditions.

The perceived sweetness in raspberry fruit comes from sugars, $40-50 \%$ being fructose, $30-40 \%$ glucose, and 10-20\% sucrose (Wang et al., 2009). Acidity is caused by the high concentration of organic acids, citric acid being the most important. Usually warm and dry weather increases sugar content and decreases acidity in raspberry fruit (Jennings, 1988; M alowicki et al., 2008). However, lower sugar content was observed in the primocane-type raspberry 'Polka' fruit when grown in high tunnels compared to an open field environment (Król-Dyrek and Siwek, 2015). This study indicates parameters other than the temperature difference between the tunnel and open field influenced this quality trait.

Rubus berries are a rich source of antioxidants and other bioactive compounds. The most important antioxidants in raspberry fruit are phenolic compounds and ascorbic acid (vitamin C) (Beekwilder et al., 2005). Among the ten raspberry genotypes studied by Mazur et al. (2014a), the main phenolic compounds were ellagitannins (57\%) and anthocyanins ( $42 \%$ ). The contents of total phenolics, flavonoids, and anthocyanins may be used to describe the antioxidant activity and thus potential health benefits of 
raspberry fruit (Wang and Lin, 2000; Liu et al., 2002; Anttonen and Karjalainen, 2005). Antioxidant activity is strongly correlated with the total phenolic concentration in raspberries (Deighton et al., 2000; Connor et al., 2005).

Temperature has contrasting effects on bioactive compounds in raspberry fruit (Remberg et al., 2010).

Lower temperatures increase berry size through increased moisture content, therefore decreasing concentrations of bioactive compounds when expressed on a fresh weight basis (dilution effect). Vitamin C was an exception, which increased even on a fresh weight basis at low temperatures. However, since large berry size is an important quality parameter for commercial production, Remberg et al. (2010) recommended relatively low temperatures, 12 to $18^{\circ} \mathrm{C}$, during the ripening of raspberry fruit.

Remberg et al. (2010) also suggested that fluctuations in temperature may enhance the accumulation of bioactive compounds in raspberry fruit, especially when compared to constant temperatures. Interestingly, long day conditions during fruit growth have also been shown to increase the concentrations of vitamin C, total phenolics, organic acids, and antioxidant capacity, while reducing the sugar content in raspberry fruit (M azur at al., 2014b). In addition to photoperiod, light spectral composition may also affect berry quality; in our previous study, ellagic acid in raspberry fruit was increased under the film absorbing far red light, while the sugar:acid ratio was slightly reduced (Palonen et al., 2011).

The aim of our present study was to examine how high tunnel growing conditions affect the yield and berry quality, including sugar content, acidity, and the contents of total phenolics, as well as the antioxidant capacity, in three floricane raspberry cultivars under Northern conditions.

\section{M aterial and M ethods}

\subsection{Plant material and experimental design}

The experiment was conducted at the University of Helsinki research field in Viikki $\left(60^{\circ} 13^{\prime} \mathrm{N} ; 25^{\circ} 1^{\prime} \mathrm{E}\right)$ during growing season 2015 using floricane raspberry cultivars 'Glen Ample', 'Glen Dee', and 'M aurin M akea'. The 
experiment was set up as an identical RCBD in a polyethylene tunnel and an adjacent open field. In each environment (tunnel versus field), plants were grown in three rows (blocks). In the tunnel environment, each row had five plants each of the three different cultivars, while in the open field, each row had six plants each of the three different cultivars. This experiment was part of a larger variety trial which included six different raspberry genotypes.

'Glen Ample' and 'Glen Dee' are releases by the James Hutton Institute, Scotland. 'M aurin Makea' was discovered as an open-pollinated seedling in a raspberry breeding population at the Natural Resources Institute, Finland and released in 1996. It is known for its excellent winter hardiness and good fruit flavor.

\subsection{Growing conditions}

The experiment was established in 2014 in sandy soil on a gentle South-facing slope. In the open field, the raised raspberry beds were covered with black woven polypropylene fabric (M yPex®). White clover (Trifolium repens, cv. Grassland Huia) at the rate of 10000 seeds $/ \mathrm{m}^{2}$ was sown between the rows. The polyethylene tunnel ( $8 \mathrm{~m} \times 35 \mathrm{~m}, 4 \mathrm{~m}$ high) was oriented South-to-North and covered with clear polyethylene (Folitec UV M 42, Folitec, Westerburg, Germany). In the tunnel, the plants were grown in 10-L pots filled with peat (OPM 630 W, Kekkilä Oy, Vantaa, Finland). The tunnel floor was covered with white woven polypropylene fabric (MyPex®). The three rows were spaced $2.40 \mathrm{~m}$ apart in the tunnel and $2.60 \mathrm{~m}$ apart in the open field. Plant spacing within a row was $40 \mathrm{~cm}$ in the tunnel and $50 \mathrm{~cm}$ in the open field.

Tunnel plastic was removed for the winter on 30 October 2014 and replaced on 27 April 2015. The tunnel was ventilated mainly through the tunnel doors at either end. Tunnel plants were fertigated through drip irrigation three times a day with a 0.01\% compound fertiliser, Taimi-Superex (NPK 19-4.4-20.2 plus microelements) (Kekkilä Oy, Vantaa, Finland), from 16 M ay through 5 June, and with a mixture of TaimiSuperex and Turve-Superex (NPK 12-4.7-27.1 plus microelements) (0.08\%) from 6 June through 19 August. Plants in the open field were fertigated through trickle irrigation system using the same fertilisers six times 
97 during the growing season. One to two floricanes per plant were grown in the tunnel and one to three in

98 the open field. New primocanes were allowed to grow freely during the experiment.

99 A bumblebee (Bombus terrestris) hive (M inipol, Koppert Biological Systems, Romulus, MI, USA) was placed 100 in the tunnel to ensure pollination. No chemical control of pests or diseases was used in the experiment. In 101 the tunnel, biological pest control included Amblyseius cucumeris to control thrips, Phytoseiulus persimilis 102 to control spider mites, and BerryProtect tubes containing different species (Aphidius ervi, A. matricariae, 103 A.colemani, Ephedrus cerasicola, Praon volucre, Aphelinus abdominalis) were used to control aphids (Biotus 104 Oy, Forssa, Finland).

105 Temperature data in the open field are from the Finnish M eteorological Institute (Figure 1). Tunnel

106 temperatures were measured in 30-minute intervals throughout the experiment. Light spectral

107 composition in the open field and the tunnel was recorded on 15 September 2015 (Figure 2). 

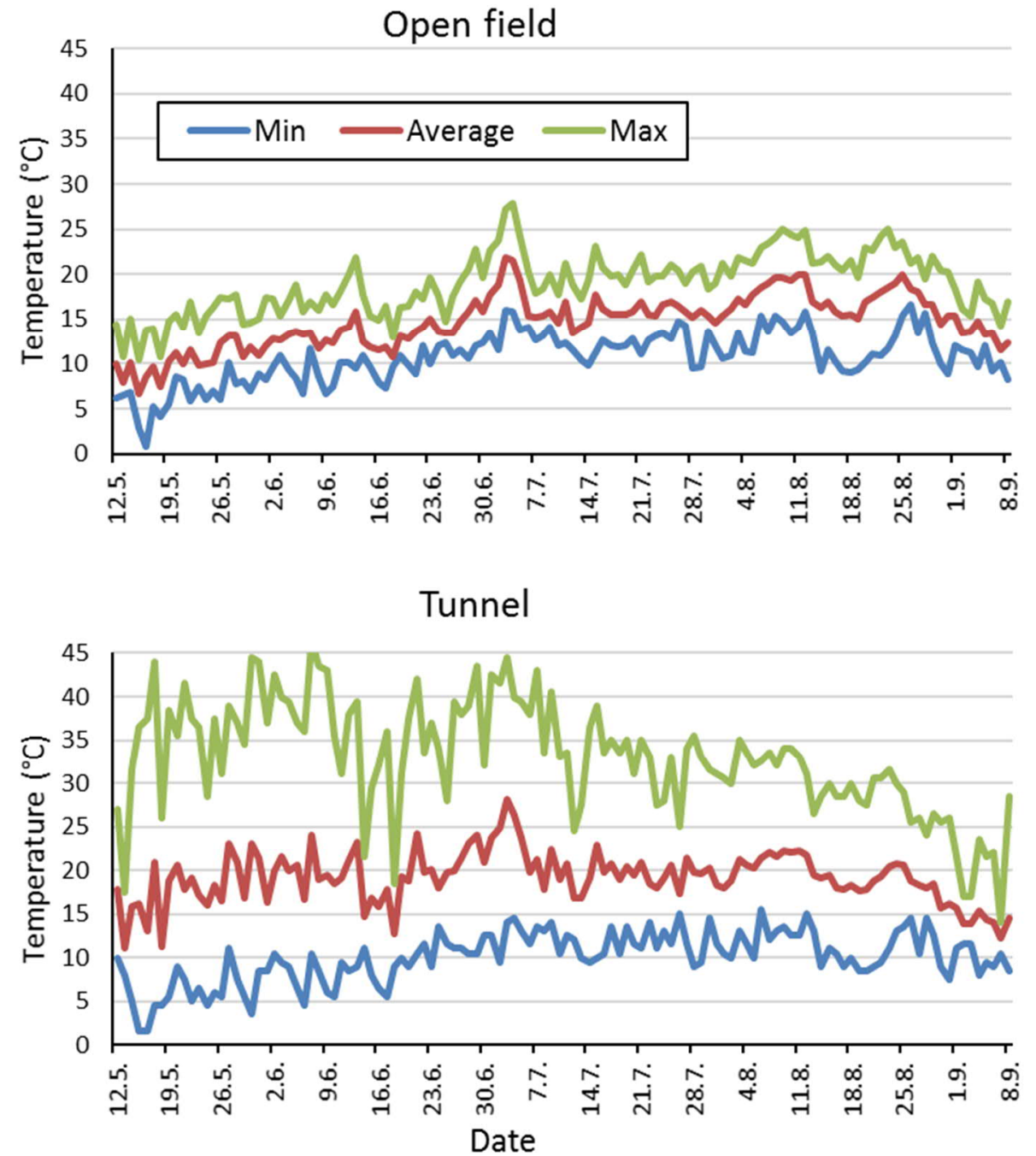

110 Figure 1. Daily average, minimum and maximum temperatures in the open field and high tunnel during the 111 growing season 2015. 


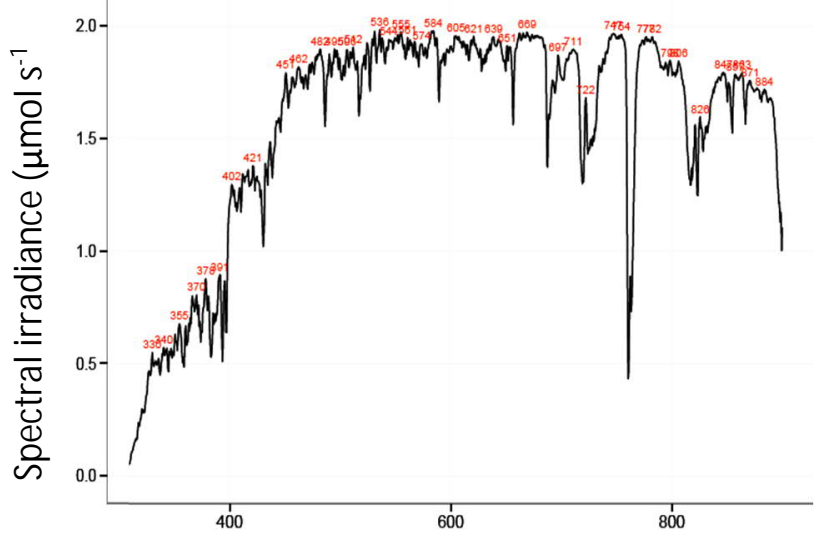

Tunnel

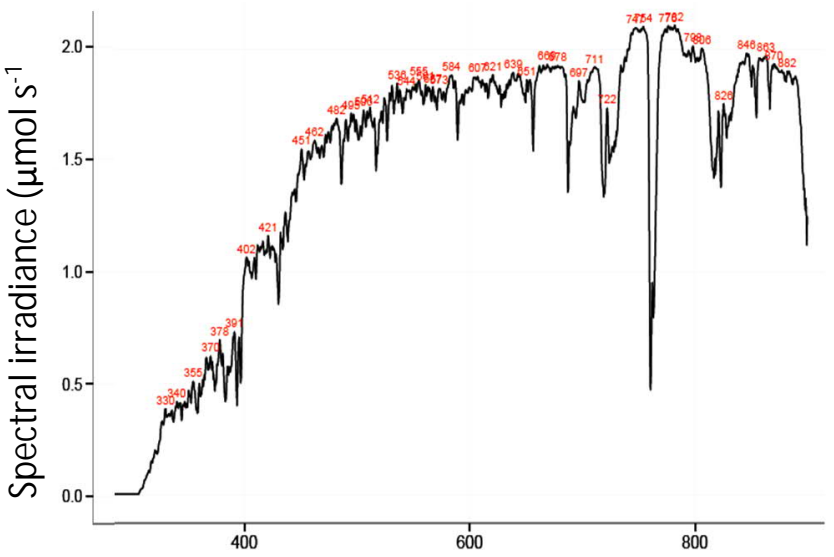

Wavelength $(\mathrm{nm})$

126 Figure 2. Spectral composition of light as a function of wavelength in the open field and high tunnel on 15

127 September 2015.

129 2.3. Harvesting and sample preparation

130 Raspberry fruits were harvested three times a week and were weighed and counted to determine total

131 yield and the number of berries per cane. For chemical analyses of fruit quality, 150 to $200 \mathrm{~g}$ of berries per

132 block were sampled and immediately frozen at $-20^{\circ} \mathrm{C}$ and held at $-20^{\circ} \mathrm{C}$ until analyses. To measure soluble 133 solids (SS) and titratable acidity (TA), samples were taken four times during the harvest season, and three 
134 times for analyses of total phenolics and antioxidant capacity. Frozen berries were thawed at room

135 temperature $\left(22^{\circ} \mathrm{C}\right)$ four hours before sample preparation.

\subsubsection{Soluble solids, $\mathrm{pH}$ and titratable acidity}

139 Using a hand held potato presser, $100-120 \mathrm{~g}$ of fruit was macerated, and then incubated in a $100 \mathrm{ml}$ 140 decanter until the upper cloudy fraction could be discarded, the clear fraction of the sample being used for

141 the analyses. Three replicate subsamples were taken and measured for their concentration of SS ( ${ }^{\circ} \mathrm{Brix}$ )

142 with an analogical refractometer (M aster, Atago, Japan).

143 To measure TA, a $5.0 \mathrm{~g}$ aliquot of clear fruit juice was added to $25 \mathrm{ml}$ of ultra pure water in a decanter. The $144 \mathrm{pH}$ was then measured with a M etrohm $744 \mathrm{pH}$ meter (M etrohm AG, Herisau, Switzerland) and the TA was 145 measured with a buret and $0.1 \mathrm{M} \mathrm{NaOH}$. The amount of $\mathrm{NaOH}$ needed to reach a pH of 8.1 was quantified 146 and used to calculate the concentration (w/w) of citric acid in the sample juice; in order to neutralise 1 147 mole of citric acid, three moles of $\mathrm{NaOH}$ is required.

$148 \quad$ 2.4.2. Antioxidant activity and total phenolics

149 Using a blender (Waring Blendor Deluxe, Conair Corporation, NJ, USA), 100-120 g of fruit was pureed. The 150 homogenised fruit puree $(5 \mathrm{~g})$ was extracted with $70 \%$ ethanol $(15 \mathrm{ml})$ in a $50 \mathrm{ml}$ tube at $+4^{\circ} \mathrm{C}$ for 17 hours. 151 According to Addai et al. (2013), recovery of antioxidant compounds using an ethanol extraction is 152 sufficient for ferric reducing ability of plasma (FRAP) and total phenolics measurement. The samples were 153 then centrifuged at $4600 \mathrm{rpm}$ for $10 \mathrm{~min}$ and the pellet discarded. Lighting in the laboratory was kept dim 154 and the tubes were wrapped in aluminum foil to prevent phenolic compounds from breaking down during 155 the analysis. Extracts were stored at $-20^{\circ} \mathrm{C}$ and always handled in low lighting.

156 Samples were diluted with ultra pure water 1:10 (v/v) to determine the FRAP using a modified version of 157 the Benzie and Strain (1996) method. The FRAP reagent was prepared each day according to Benzie and 
158 Strain (1996) and Deighton et al. (2000) protocols. We pipetted $1 \mathrm{ml}$ of the FRAP reagent and $30 \mu \mathrm{l}$ of

159 sample into a cuvette and, after incubation for 4 min at room temperature, the absorbance at $593 \mathrm{~nm}$ was

160 read using a spectrophotometer (UV 1601, Shimadzu, Japan). The antioxidant activity in the sample (FRAP)

161 was expressed as $\mu \mathrm{mol}$ Fe(II)-TPTZ/ g FW.

162 The concentration of total phenolics (TP) was determined using the Fast Blue BB (FBBB) method (M edina,

163 2011a). Since the optimal concentration of phenolics in the sample corresponds to a gallic acid

164 concentration of 50-400 $\mu \mathrm{g} / \mathrm{ml}$ (Medina, 2011b), samples were diluted with ultra pure water 1:10 (v/v).

$165 \mathrm{Next}, 100 \mu \mathrm{l}$ of $0.1 \%$ FBBB reagent and $100 \mu \mathrm{l}$ of $5 \% \mathrm{NaOH}$ were added into $1 \mathrm{ml}$ of sample and the mixture

166 was incubated at room temperature for 90 mins. The absorbance at $420 \mathrm{~nm}$ was then read using a

167 spectrophotometer (UV 1601, Shimadzu, Japan). The concentration of TP in the sample was expressed as $168 \mathrm{mg} \mathrm{GAE} / \mathrm{g}$ FW.

\subsection{Statistical analysis}

171 The experimental design was a RCBD where the three blocks were nested in a growing condition treatment.

172 The parameters of yield and berry quality were statistically analysed by a two-way ANOVA by means of a

173 mixed model with growing condition treatment and cultivar as the fixed factors and block (nested in

174 growing condition) as the random factor. The SAS M ixed procedure (SAS 9.4, SAS Institute Inc.) (Littell et al., 175 2006) was applied to fit the model using the restricted maximum likelihood (REM L) estimation method. The 176 data from the open field and the tunnel were analysed separately using ANOVA (IBM SPSS Statistics,

177 program 23) with cultivar as an independent factor. In cases where conditions for analysis of variance were 178 not fulfilled, a non-parametric Kruskal-Wallis test was used. Data for berry quality measurements from

179 different dates were pooled and the means were used in the analyses. Cultivar means were separated using 180 Tukey's test at a significance level of $P \leq 0.05$. 
3.1. Yield and berry size

184

Berries were harvested for 47 days in the open field and 62 days in the high tunnel. The harvest started with the cultivars 'Glen Ample' and 'Maurin Makea' on 1 July in the tunnel and 24 July in the open field (Fig. 3). For 'Glen Dee', the first berries were harvested on 13 July in the tunnel and 29 July in the open field. 187 Total yield per cane across all cultivars was, on average, 99\% higher in the tunnel compared to the open 188 field $(P<0.001)$. This was due to the higher number of berries in the tunnel-grown canes $(P<0.001)$, since 189 berry size was not affected by growing condition, but was significantly affected by cultivar $(P=0.007)$, with 190 'Glen Dee' having the largest berries. Cultivars differed in total yield ( $P=0.009)$, as well as in their response 191 to growing conditions due to a highly significant interaction observed between growing condition and 192 cultivar $(P<0.001)$. Pronounced cultivar differences in the total yield were observed in the open field but 193 not in the tunnel (Table 1). 'M aurin Makea' and 'Glen Dee' produced significantly lower yields in the open 194 field than in the tunnel $(\mathrm{P}<0.001)$, however, 'Glen Ample' was equally productive in both growing 195 conditions (Fig. 3). For 'M aurin Makea', both berry number $(P=0.001)$ and berry size $(P<0.001)$ were 196 smaller in the open field than in the tunnel. There was large variation in 'M aurin Makea' yield between the 197 open field blocks, and a few berries suffered pest damage. Overall, berry weight declined as the harvest 198 season progressed (Fig. 4). In the tunnel, some of the 'Glen Ample' fruit were crumbly, and, due to high 199 variation, the differences in berry size between the cultivars were not significant in the tunnel. 
202 Table 1. Total yield, number of berries and average berry weight in three raspberry cultivars grown in open

203 field and high tunnel environments, 2015. The values are means of three replicates of five to six plants 204 each and followed by \pm SE.

$\begin{array}{ll}\text { Yield (g/cane) } & \text { Number of berries } \quad \text { Berry weight }(\mathrm{g}) \\ & \text { / cane }\end{array}$

\begin{tabular}{llll}
\hline Open field & & & \\
'Glen Ample' & $1003 \pm 86 \mathrm{a}$ & $171 \pm 4 \mathrm{a}$ & $5.6 \pm 0.4 \mathrm{a}$ \\
'Glen Dee' & $367 \pm 15 \mathrm{~b}$ & $59 \pm 1 \mathrm{~b}$ & $6.2 \pm 0.3 \mathrm{a}$ \\
'M aurin Makea' & $272 \pm 20 \mathrm{~b}$ & $71 \pm 5 \mathrm{ab}$ & $3.6 \pm 0.1 \mathrm{~b}$ \\
$\mathrm{P}$ & $<0.001$ & $<0.001$ & 0.001
\end{tabular}

Tunnel

$\begin{array}{llll}\text { 'Glen Ample' } & 905 \pm 102 \mathrm{~b} & 224 \pm 41 & 4.6 \pm 0.8 \\ \text { 'Glen Dee' } & 1272 \pm 68 \mathrm{a} & 203 \pm 5 & 6.3 \pm 0.2 \\ \text { 'Maurin M akea' } & 1082 \pm 72 \mathrm{ab} & 227 \pm 17 & 4.6 \pm 0.1 \\ \mathrm{P} & 0.052 & \text { Ns. } & \text { Ns. }\end{array}$

205 Ns. =not significant

206 Cultivar means followed by a different letter, for both growing conditions separately, are significantly 207 different at $\mathrm{P}<0.05$ by Tukey's test. 

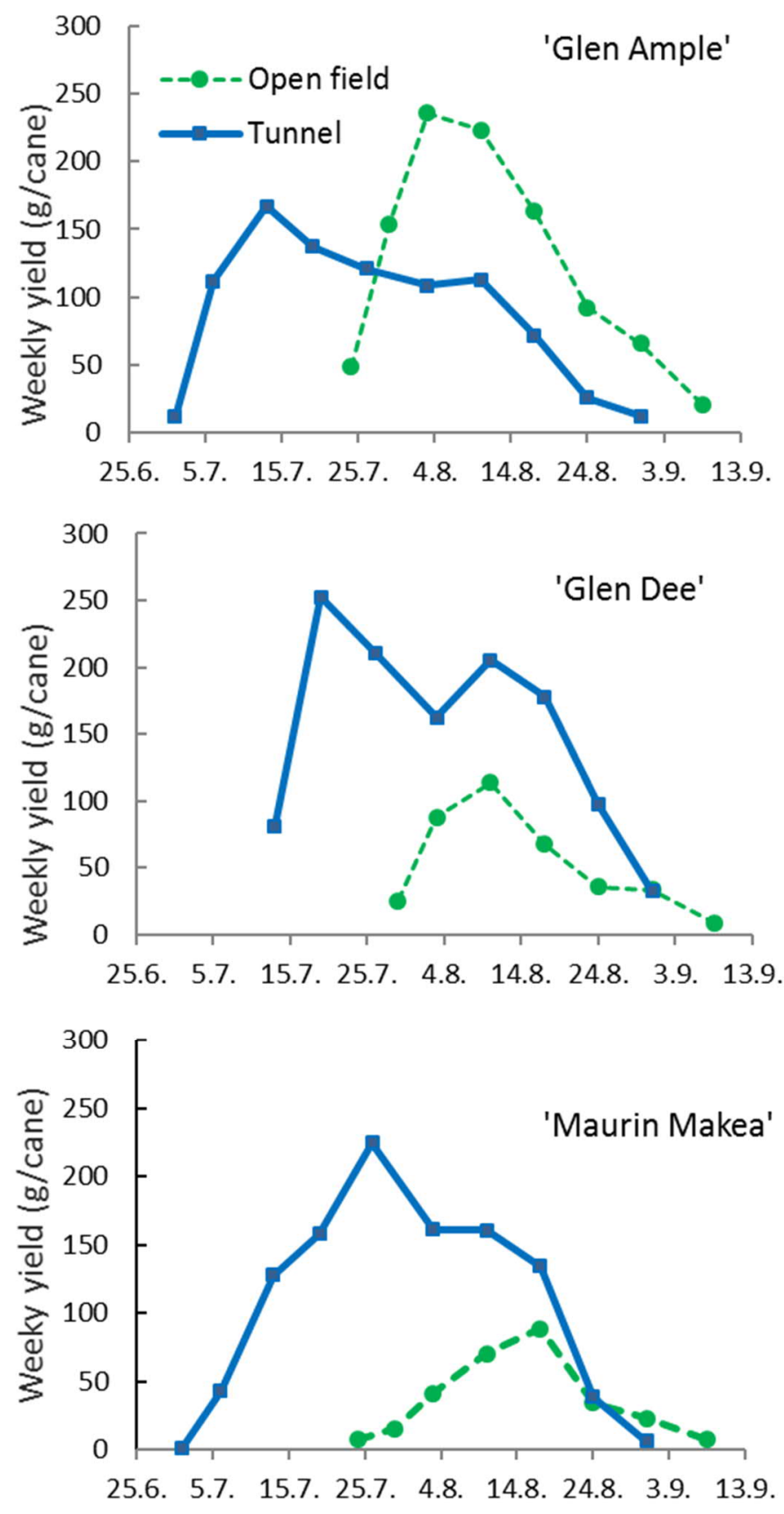

Date

209 Figure 3. Weekly marketable fruit yield per cane in three raspberry cultivars grown in open field and high 210 tunnel environments, 2015. The values are means of three replicates of five to six plants each. 

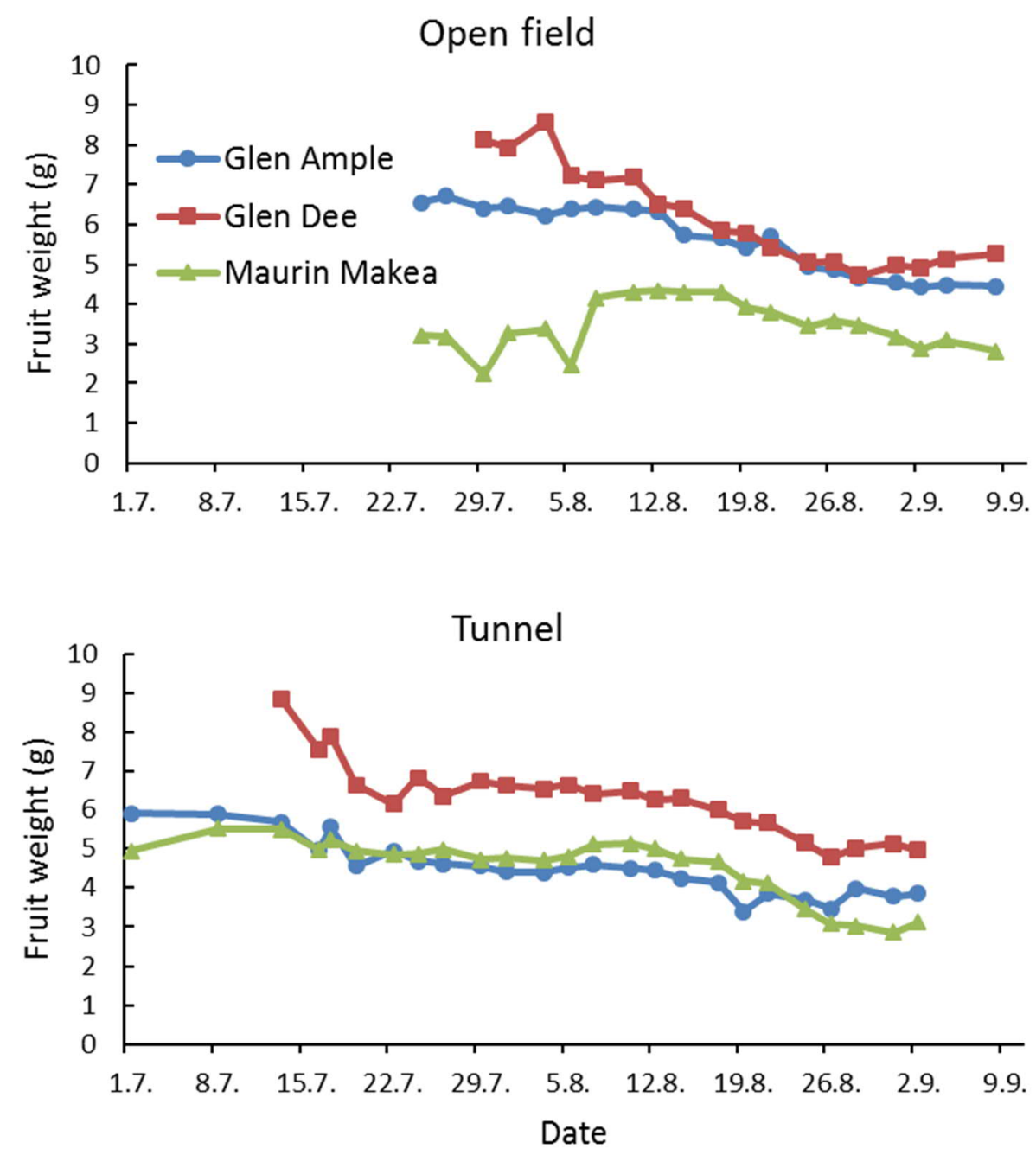

213 Figure 4. Average berry weight during the harvest season in three raspberry cultivars grown in open field 214 and high tunnel environments, 2015. The values are means of three replicates of five to six plants each.

\subsection{Berry quality}

217 Berry sugar content and acidity were significantly affected by the growing conditions (Table 2). A higher 218 content of SS ( ${ }^{\circ} \mathrm{Brix}$ ) and TA were observed in berries from the open field, while the pH was lower. There 219 was no difference, however, in the sugar:acid ratio between the two growing conditions. Between the 220 cultivars, there were also differences; sugar content was lowest in 'Glen Dee' and the pH was lowest in 221 'Glen Ample' (Table 2). 
222 In the open field, both $\mathrm{pH}(\mathrm{P}=0.002)$ and TA $(P=0.012)$ were significantly different between the cultivars, 223 with a pH of 3.00 for 'Glen Ample', 3.05 for 'M aurin M akea' and 3.07 for 'Glen Dee'. 'Glen Dee' berries were 224 also the least acidic based on the measurement of TA (Fig. 5). In the open field, the sugar content was 225 highest for 'M aurin M akea' and lowest for 'Glen Dee', but, according to the Kruskal-Wallis test, the 226 difference was not significant $(P=0.051)$. In the tunnel, the differences between the cultivars in sugar 227 content, TA and pH were less pronounced and not significantly different.

229 Table 2. The influence of growing conditions (open field or high tunnel) and cultivar on the concentration of 230 soluble solids ('Brix) and titratable acids (TA), sugar:acid ratio, and pH in raspberry fruit juice. The values 231 are means of three replicates of five to six plants each and four sampling times, followed by \pm SE.

$$
{ }^{\circ} \text { Brix } \quad \text { TA }(g / 100 \mathrm{~g} \mathrm{FW}) \text { Sugar:acid ratio } \mathrm{pH}
$$

\begin{tabular}{lllll}
\hline Growing condition $(\mathrm{G})$ & & & & \\
Open field & $10.0 \pm 0.3$ & $2.06 \pm 0.03$ & $4.86 \pm 0.11$ & $3.04 \pm 0.01$ \\
Tunnel & $8.6 \pm 0.2$ & $1.77 \pm 0.02$ & $4.88 \pm 0.12$ & $3.26 \pm 0.01$ \\
$P$ & $<0.001$ & $<0.001$ & Ns. & $<0.001$
\end{tabular}

Cultivar (C)

$\begin{array}{lllll}\text { 'Glen Ample' } & 9.5 \pm 0.2 \mathrm{a} & 1.94 \pm 0.07 & 4.93 \pm 0.15 & 3.12 \pm 0.05 \mathrm{a} \\ \text { 'Glen Dee' } & 8.7 \pm 0.3 \mathrm{~b} & 1.87 \pm 0.04 & 4.66 \pm 0.09 & 3.17 \pm 0.04 \mathrm{~b} \\ \text { 'Maurin Makea' } & 9.7 \pm 0.6 \mathrm{a} & 1.94 \pm 0.09 & 5.02 \pm 0.14 & 3.17 \pm 0.05 \mathrm{~b} \\ \mathrm{P} & 0.008 & \text { Ns. } & \text { Ns. } & 0.001\end{array}$

Interaction
$\mathrm{G} \times \mathrm{C}$
Ns. $\quad 0.006$
Ns.
Ns. 


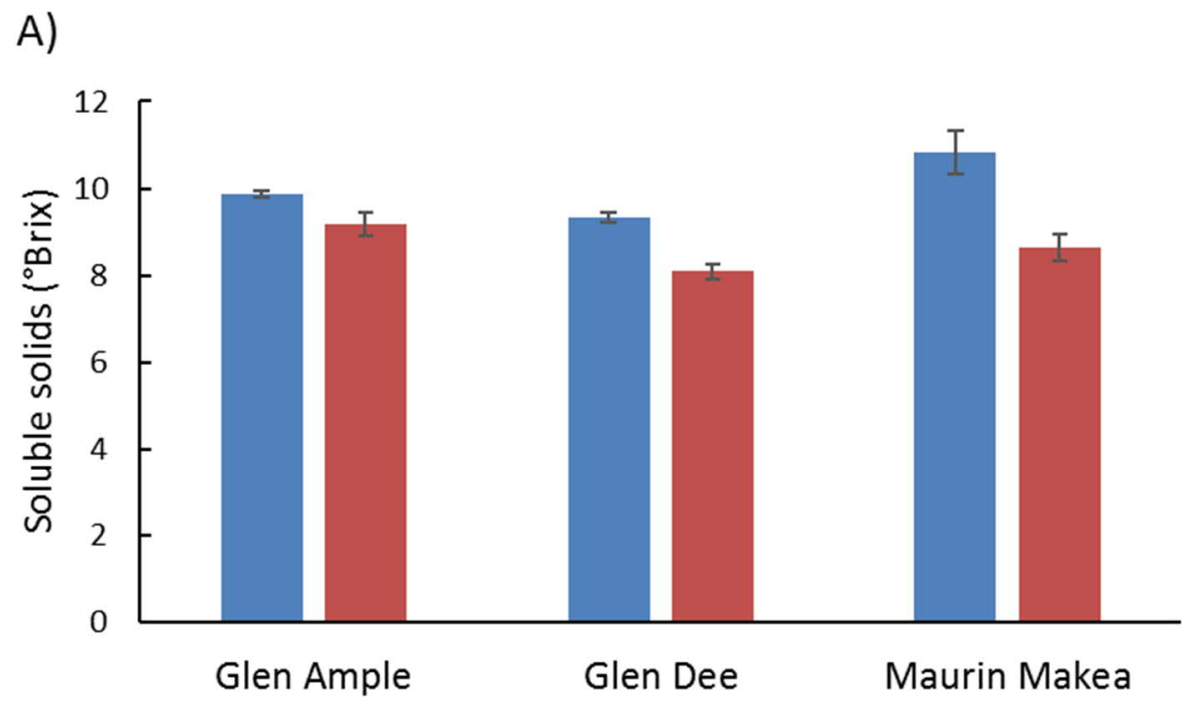

B)

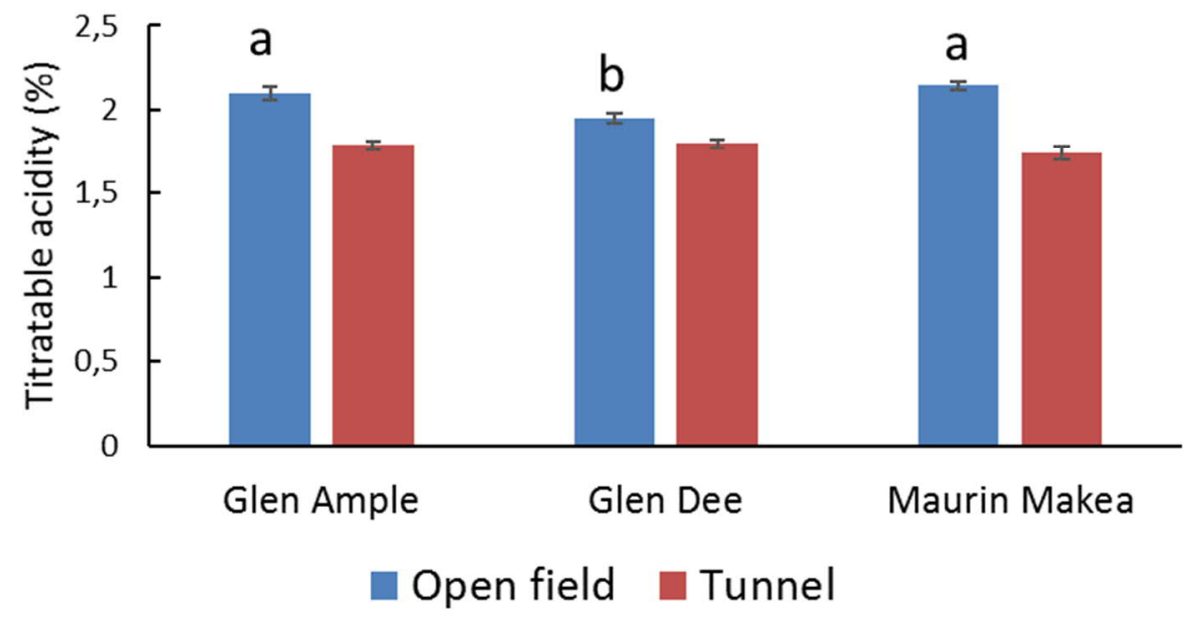

236 Figure 5. Concentrations of $A$ ) soluble solids ( ${ }^{\circ}$ Brix) and B) titratable acids (\%) in the fruit juice of three

237 raspberry cultivars grown in open field and high tunnel environments, 2015 . The values are means of three

238 replicates of five to six plants each and four sampling times. Vertical bars present \pm SE. Cultivar means

239 marked by a different letter, for both growing conditions separately, are significantly different at $\mathrm{P}<0.05$

240 by Tukey's test.

242 Examined all together, antioxidant activity was not affected by growing conditions or cultivar (Table 3).

243 When analysing data from the two growing conditions separately, however, cultivar differences were 
244 observed in the open field ( $P=0.042)$, with antioxidant activity being higher for 'Glen Ample' berries than 245 'Glen Dee' (Fig. 6).

246 The TP content was not affected by growing conditions, but was affected by cultivar, with 'Glen Ample' 247 being significantly higher than 'Glen Dee' (Table 3). Furthermore, when the data from the two growing 248 conditions were analysed separately, this cultivar effect was still found to be significant in the open field (P $249=0.018$ ), where 'Glen Dee' berries had the lowest concentration of TP (Fig. 6). Additionally, a correlation 250 between antioxidant activity and the concentration of TP was also observed $(r=0.59, P<0.001)$.

252 Table 3. The influence of growing conditions (open field or high tunnel) and cultivar on the antioxidant 253 activity (FRAP) and concentration of total phenolics in raspberry fruit in 2015 . The values are means of 254 three replicates of five to six plants each and three sampling times and followed by \pm SE.

$$
\text { FRAP ( } \mu \mathrm{mol} \text { Fe(II)/g FW) Total phenolics (mg GAE/g FW) }
$$

\begin{tabular}{lll}
\hline Growing condition $(\mathrm{G})$ & & \\
Open field & $23.6 \pm 0.5$ & $3.8 \pm 0.3$ \\
Tunnel & $22.6 \pm 0.7$ & $4.1 \pm 0.2$ \\
$P$ & Ns. & Ns.
\end{tabular}

Cultivar (C)

$\begin{array}{lll}\text { 'Glen Ample' } & 24.3 \pm 1.1 & 4.4 \pm 0.3 \mathrm{a} \\ \text { 'Glen Dee' } & 22.3 \pm 0.3 & 3.3 \pm 0.2 \mathrm{~b} \\ \text { 'Maurin Makea' } & 22.7 \pm 0.6 & 4.1 \pm 0.2 \mathrm{ab} \\ \mathrm{P} & \text { Ns. } & 0.011\end{array}$

Interaction
$G \times C$
Ns.
Ns. 


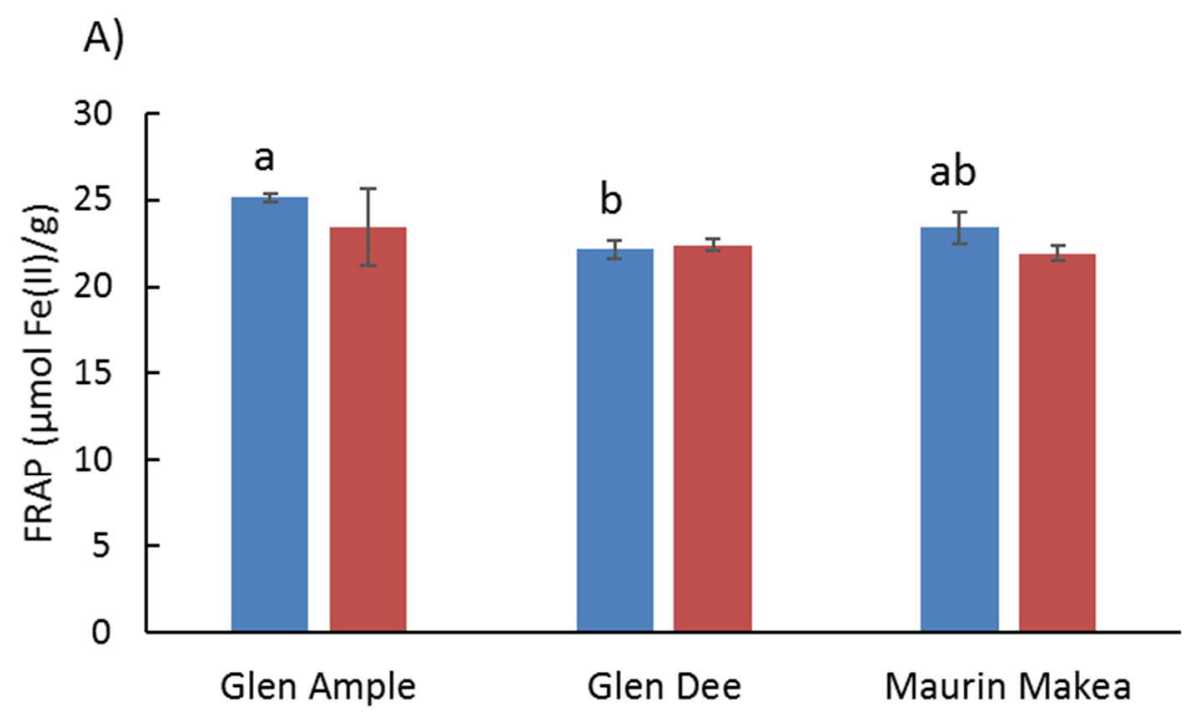

B)

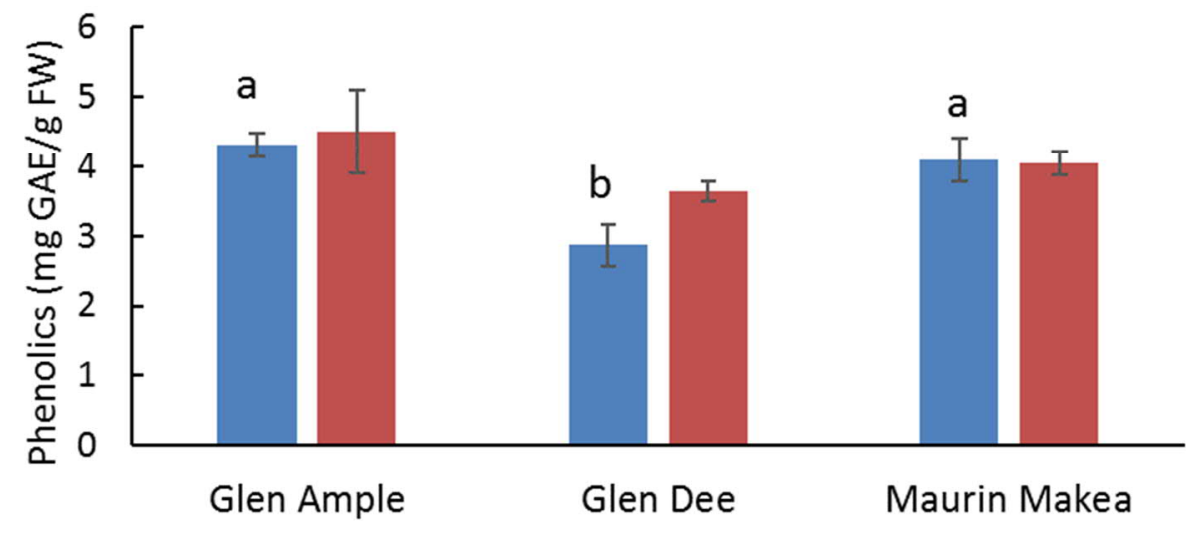

259 Figure 6. The A) antioxidant activity (FRAP) and B) concentration of total phenolics in the fruit of three 260 raspberry cultivars grown in open field and high tunnel environments, 2015 . The values are means of three 261 replicates of four plants each and three sampling times. Vertical bars present \pm SE. Cultivar means marked 262 by a different letter, for both growing conditions separately, are significantly different at $P<0.05$ by 263 Tukey's test. 
To our knowledge, this is the first study to report the effect of protected cultivation of raspberry in polyethylene tunnels on fruit quality in Northern $\left(60^{\circ} 13^{\prime} \mathrm{N}\right)$ conditions, where light conditions, including photoperiod and light spectral composition, are notably very different from other raspberry production areas. Fruit yield per cane was doubled in the tunnel compared to the open field. This has also been noted by previous studies for tunnel-grown floricane raspberry cultivars, with more than double higher yields seen by Hanson et al. (2011) in M ichigan, USA, Fernandez and Perkins-Veazie (2013) in North Carolina, USA, and Xu et al. (2014) in Quebec, Canada. Cropping potential is largely determined by the conditions during the season preceding the harvest year. In our experiment, the plants were also grown in the same conditions the previous year. In an earlier study we observed that the number of flowers (cropping potential) in 'M aurin Makea' long cane plants increased by $28-40 \%$ in tunnel-grown canes compared to the field-grown canes, depending on the duration of cold storage (Palonen et al., 2015).

The temperatures inside the tunnel were relatively high, especially between late M ay and early July. Remberg et al. (2010) recommended relatively low temperatures, 12 to $18^{\circ} \mathrm{C}$, for protected raspberry production since berry weight decreases with increasing post-flowering temperature. Although the temperatures recorded in our tunnel were much higher, the berry size was not reduced. In the study by Fernandez and Perkins-Veazie (2013), berry size was not affected by tunnel growing conditions either. Some of the 'Glen Ample' fruit in the tunnel were crumbly, a disorder that is increasingly common in Europe, and has recently been shown to depend on seasonal and environmental, as well as genetic, factors 284 (Graham et al., 2015). The tunnel growing conditions may have influenced the expression of this condition 285 in our experiment.

Berries grown in the open field had higher contents of SS ( ${ }^{\circ}$ Brix) and higher TA than those grown in the high tunnel, whereas the sugar:acid ratio was not affected. Furthermore, the differences between the cultivars regarding these attributes were more pronounced in the open field. Sugar content and acidity only partially explain sensory taste, with 15-20 volatile aroma compounds detected in raspberry fruit significantly affecting its flavor (Larsen and Poll, 1990). Sensory sweetness and sensory acidity do correlate with 
291

measured sucrose content and sugar:acid ratio (Stavang et al., 2015), although the sugar:acid ratio may be more closely related to fruit maturity.

Warm and dry weather increases sugar content and decreases acidity in raspberry fruit (J ennings, 1988). Malowicki et al. (2008) observed that, for raspberries grown in Oregon and Washington, the SS were higher and TA lower for the growing site with higher average temperatures. In our study, SS was, on average, $10.0 \%$ in the open field and $8.6 \%$ in the high tunnel, and was lowest for 'Glen Dee'. Lower SS in the tunnel compared to the open field has also been reported for the primocane-type raspberry 'Polka' in Poland (Król-Dyrek and Siwek, 2015). Norwegian researchers have reported SS contents of 8.3\% for 'Glen Ample' in the open field $\left(61^{\circ} 11^{\prime} \mathrm{N}\right.$ ) (M azur et al., 2014a) and, in another study, 9.5\% in a polyethylene tunnel $\left(59^{\circ} 40^{\prime} \mathrm{N}\right)$ (Remberg et al., 2010). The SS for 'Glen Ample' in our study was 9.9\% in the open field and 9.2\% in the tunnel. The TA measured in our study for 'Glen Ample' in the open field was exactly the same (2.1 g/100 g FW) as observed in the open field in Norway (M azur et al., 2014a). For cultivars 'Glen Clova' and 'Glen Prosen', TA concentrations of $1.3 \%$ and $2.0 \%$, respectively, have been reported; the average for 40 red raspberry genotypes being 1.6\% (Weber et al., 2008)

Raspberry plant photosynthesis declines as temperatures rise above $25^{\circ} \mathrm{C}$ (Stafne et al., 2001). It is possible that high temperatures inside the tunnel led to decreased transport of photosynthates into the fruit. Environmental conditions including temperature, light and humidity also affect the biosynthesis of flavor volatiles (Paterson et al., 2013). We observed that for some cultivars flavor did not develop as well in the tunnel as in the open field.

Fruit bioactive properties, including phenolic compounds and antioxidant activity, were not affected by the high tunnel. In 'Glen Ample' fruit, TP concentrations of $1.9 \mathrm{mg} \mathrm{GAE} / \mathrm{g}$ FW in the open field (M azur et al., 2014a) and 2.6 mg GAE/g FW in the tunnel (Remberg et al., 2010) have been reported. In these studies, the Folin-Ciocalteu method was used. In 'Glen Ample', we obtained measures of, on average, 4.4 mg GAE/g FW using the Fast Blue BB method which has been observed to yield a 2.6-fold increase in concentration of TP, compared to the Folin-Ciocalteu method (Lester et al., 2012). TP concentrations for 'M aurin M akea' and 
316 'Glen Dee' fruit have not been previously reported in the literature, though, for 12 red raspberry cultivars

317 grown in Eastern Finland, the phenolic concentrations ranged from 1.92 to 3.59 mg/g FW (Folin-Ciocalteu)

318 (Anttonen and Karjalainen, 2005). Weber et al. (2008) reported TP concentrations of 3.78 and $3.70 \mathrm{mg} / \mathrm{g}$

319 FW in cultivars 'Glen Clova' and 'Glen Prosen', respectively; the average for 40 red raspberry genotypes being $4.21 \mathrm{mg} / \mathrm{g}$ FW. Comparing results from different studies is further complicated by the fact that the recovery of phenolic compounds, and thus their measured concentration, is dependent on the extracting solvent used (Addai et al., 2013).

M any environmental factors influence the biosynthesis of phenolic compounds in plants, and the regulation appears to be complex. High temperatures, for example, inhibit anthocyanin production in apple (Lin-Wang et al., 2011). On the other hand, in strawberry, high temperature $\left(30 / 22^{\circ} \mathrm{C}\right.$ day/night) increased the content of phenolic compounds and antioxidant capacity (Wang and Zheng, 2001). Additionally, an interaction between the genotype and environmental conditions on the antioxidant activity in raspberry was observed by Hanson et al. (2011). In our study as well, high temperatures inside the tunnel may have changed the 329 fruit's chemical composition and relative amounts of individual phenolic compounds, although the total concentration of phenolics was not affected. Cultivar differences were pronounced, with 'Glen Ample' fruit having the highest concentration of TP and 'Glen Dee' the lowest. A direct relationship between the antioxidant capacity and the content of TP, especially anthocyanins and ellagitannins, has been shown for raspberry fruit (Wang and Lin, 2000; Liu et al., 2002; Remberg et al., 2010). A correlation was observed in our study as well. Antioxidant activity showed a trend similar to TP, although the differences between the cultivars were not as pronounced. Weber et al. (2008) reported FRAP values of 21 and 20 Trolox equivalents in cultivars 'Glen Clova' and 'Glen Prosen', respectively; the average for 40 red raspberry

337 genotypes being 25. The average in our study was $23.1 \mu \mathrm{mol} \mathrm{Fe}(\mathrm{II}) / \mathrm{g}$, across all cultivars and both growing 338 conditions.

339 The data presented here can not be used to determine a single environmental factor that caused the differences in berry quality, but rather to compare two different production systems and environments. 
341 Not only were temperature and light conditions, humidity and windiness different, but the plants were

342 managed differently in each growing condition. Key production practices, such as irrigation, fertilization,

343 and growth substrate were different. Furthermore, harvest maturity affects all these measured parameters.

344 For example, TA decreases and the concentration of anthocyanins and the sugar:acid ratio (mainly due to 345 decreasing acidity) increase during raspberry fruit maturation (Stavang et al., 2015). Therefore, it is crucial 346 for the reliability of any analysis that sampled berries are in the same maturity range.

347 While the content and composition of phenolic compounds are certainly affected by environmental 348 conditions, it appears that these characteristics are more greatly affected by genotype. Anttonen and

349 Karjalainen (2005) reported large variation in fruit TP concentration between the raspberry cultivars grown 350 in Finland, ranging from $192 \mathrm{mg} / 100 \mathrm{~g}$ (FW) in 'Gatineau' to $359 \mathrm{mg} / 100 \mathrm{~g}$ (FW) in 'Ville'. Differences were 351 also observed in the contents of quercetin, ellagic acid, and anthocyanins. In our study, the open field TP 352 concentration of 'Glen Ample' was $48 \%$ higher than that of 'Glen Dee'. The highest contents of phenolics 353 have actually been measured in wild raspberry (M äättä-Riihinen et al., 2004). Weber et al. (2008) reported 354 a threefold difference in FRAP values across red raspberry genotypes. Apparently, it is more important to 355 consider the genotype grown than the influence of growing conditions, as genotype effects are far more 356 significant.

357 In conclusion, raspberry production under polyethylene tunnels may provide major benefits, as fruit yield 358 per cane was doubled in the tunnel compared to the open field, while fruit bioactive properties, including 359 phenolic compounds and antioxidant activity, were not affected. Berries grown in the open field, however, 360 contained more sugars and acids than the ones grown in the tunnel. Cultivar differences were pronounced, 361 with 'Glen Ample' and 'M aurin Makea' berries having higher phenolic concentrations and being sweeter 362 than 'Glen Dee' berries. 
We gratefully acknowledge financial support for this work from the Ministry of Agriculture and Forestry, Finland (Grant no. 1900/312/2013) and from the Maiju and Yrjö Rikala Horticultural Foundation. We also thank the technical staff at the research greenhouses and laboratories of the University of Helsinki. Professor Saila Karhu is acknowledged for her help with the statistical analysis.

371 Addai, Z.R., Abdullah, A., Mutalib, S.A., 2013. Effect of extraction solvents on the phenolic content and 372 antioxidant properties of two papaya cultivars. J. M ed. Plants Res. 7, 3354-3359.

373 Anttonen, M.J., Karjalainen, R.O., 2005. Environmental and genetic variation of phenolic compounds in red 374 raspberry. J. Food Comp. Anal. 18, 759-769.

Beekwilder, J., Hall, R.D., Ric de Vos, C.H., 2005. Identification and dietary relevance of antioxidants from raspberry. Biofactors 23, 197-205.

377 Benzie, I.F., Strain, J., 1996. The ferric reducing ability of plasma (FRAP) as a measure of "antioxidant 378 power": the FRAP assay. Anal. Biochem. 239, 70-76.

379 Connor, A.M., Stephens, M.J., Hall, H.K., Alspach, P.A., 2005. Variation and heritabilities of antioxidant 380 activity and total phenolic content estimated from a red raspberry factorial experiment. J. Am. Soc. Hortic. 381 Sci. 130, 403-411.

382 Deighton, N., Brennan, R., Finn, C., Davies, H.V., 2000. Antioxidant properties of domesticated and wild 383 Rubus species. J. Sci. Food Agric. 80, 1307-1313.

384 Fernandez, G., Perkins-Veazie, P., 2013. Yield and postharvest attributes of caneberries grown under high 385 tunnels and in the open field in North Carolina. Acta Hortic. 987, 89-98.

386 Graham, J., Smith, K., M cCallum, S., Hedley, P.E., Cullen, D.W., Dolan, A., M ilne, L., M cNicol, J.W., Hackett, 387 C.A., 2015. Towards an understanding of the control of 'crumbly' fruit in red raspberry. SpringerPlus 4, 223. 
388 Hanson, E., Von Weihe, M., Schilder, A.C., Chanon, A.M., Scheerens, J.C., 2011. High tunnel and open field 389 production of floricane- and primocane-fruiting raspberry cultivars. HortTechnology 21, 412-418.

390 Jennings, D.L., 1988. Raspberries and Blackberries: Their Breeding, Diseases and Growth. Academic Press, 391 London.

392 Król-Dyrek, K., Siwek, P., 2015. The influence of biodegradable mulches on the yielding of autumn raspberry 393 (Rubus idaeus L.). Folia Hortic. 27, 15-20.

394 Larsen, M., Poll, L., 1990. Odour thresholds of some important aroma compounds in raspberries. Z. 395 Lebensm.-Unters. -Forsch. 191, 129-131.

396 Lester, G.E., Lewers, K.S., M edina, M.B., Saftner, R.A., 2012. Comparative analysis of strawberry total 397 phenolics via Fast Blue BB vs. Folin-Ciocalteu: Assay interference by ascorbic acid. J. Food Comp. Anal. 27, $398 \quad 102-107$.

399 Lin-Wang, K., Micheletti, D., Palmer, J., Volz, R., Lozano, L., Espley, R., Hellens, R.P., Chagne, D., Rowan, 400 D.D., Troggio, M., 2011. High temperature reduces apple fruit colour via modulation of the anthocyanin 401 regulatory complex. Plant Cell Environ. 34, 1176-1190.

402 Littell, R.C., Stroup, W.W., Milliken, G.A., Wolfinger, R.D., Schabenberger, O., 2006. SAS for M ixed M odels. 403 2. Ed. SAS Institute Inc.

404 Liu, M., Li, X.Q., Weber, C., Lee, C.Y., Brown, J, Liu, R.H., 2002. Antioxidant and antiproliferative activities of 405 raspberries. J. Agric. Food Chem. 50, 2926-2930.

406 M äättä-Riihinen, K.R., Kamal-Eldin, A., Törrönen, A.R., 2004. Identification and quantification of phenolic 407 compounds in berries of Fragaria and Rubus species (family Rosaceae). J. Agric. Food Chem. 52, 6178-6187.

408 Malowicki, S.M ., Martin, R., Qian, M.C., 2008. Comparison of sugar, acids, and volatile composition in 409 raspberry bushy dwarf virus-resistant transgenic raspberries and the wild type 'M eeker' (Rubus Idaeus L.). J. 410 Agric. Food Chem. 56, 6648-6655. 
411 M azur, S.P., Nes, A., Wold, A., Remberg, S.F., Aaby, K., 2014a. Quality and chemical composition of ten red 412 raspberry (Rubus idaeus L.) genotypes during three harvest seasons. Food Chem. 160, 233-240.

413 M azur, S., Sønsteby, A., Wold, A., Foito, A., Freitag, S., Verrall, S., Conner, S., Stewart, D., Heide, O., $2014 b$. 414 Post-flowering photoperiod has marked effects on fruit chemical composition in red raspberry (Rubus 415 idaeus). Ann. Appl. Biol. 165, 1-12.

416 Medina, M. B., 2011a. Determination of the total phenolics in juices and superfruits by a novel chemical 417 method. J. Funct. Foods 3, 79-87.

418 Medina, M. B., 2011b. Simple and rapid method for the analysis of phenolic compounds in beverages and 419 grains. J. Agric. Food Chem. 59, 1565-1571.

420 Palonen, P., Karhu, S., Savelainen, H., Rantanen, M., Junttila, O., 2011. Growth and cropping of primocane 421 and biennial raspberry cultivars grown under a film absorbing far-red light. J. Hortic. Sci. Biotech. 86, 113422119.

423 Palonen, P., Pohjola, M., Karhu, S., 2015. Cropping potential of raspberry long-cane plants is affected by 424 their growing conditions and duration of cold storage. J. Hortic. Sci. Biotech. 90, 738-746.

425 Paterson, A., Kassim, A., M cCallum, S., Woodhead, M., Smith, K., Zait, D., Graham, J., 2013. Environmental 426 and seasonal influences on red raspberry flavour volatiles and identification of quantitative trait loci (QTL) 427 and candidate genes. Theor. Appl. Genet. 126, 33-48.

428 Remberg, S.F., Sønsteby, A., Aaby, K., Heide, O. M., 2010. Influence of postflowering temperature on fruit 429 size and chemical composition of Glen Ample raspberry (Rubus idaeus L.). J. Agric. Food Chem. 58, 91204309128.

431 Stafne, E.T., Clark, J.R., Rom, C.R., 2001. Leaf gas exchange response of 'Arapaho' blackberry and six red 432 raspberry cultivars to moderate and high temperatures. HortScience 36, 880-883. 
433 Stavang, J.A., Freitag, S., Foito, A., Verrall, S., Heide, O.M., Stewart, D., Sønsteby, A., 2015. Raspberry fruit 434 quality changes during ripening and storage as assessed by colour, sensory evaluation and chemical 435 analyses. Sci. Hortic. 195, 216-225.

436 Wang, S.Y., Chen, C., Wang, C.Y., 2009. The influence of light and maturity on fruit quality and flavonoid 437 content of red raspberries. Food Chem. 112, 676-684.

438 Wang, S.Y., Lin, H.S., 2000. Antioxidant activity in fruits and leaves of blackberry, raspberry, and strawberry 439 varies with cultivar and development stage. J. Agric. Food Chem. 48, 140-146.

440 Wang, S.Y., Zheng, W., 2001. Effect of plant growth temperature on antioxidant capacity in strawberry. J. 441 Agric. Food Chem. 49, 4977-4982.

442 Weber, C.A., Perkins-Veazie, P., Moore, P.P., Howard, L., 2008. Variability of antioxidant content in 443 raspberry germplasm. Acta Hortic. 777, 493-497.

444 Xu, Q., Gosselin, A., Desjardins, Y., M edina, Y., Gauthier, L., 2014. Red raspberries production under high 445 tunnel, umbrella-like structure and open field under northern Canadian climate. Acta Hortic. 1037, 771-776. 